\title{
DNA multigene sequencing of topotypic specimens of the fascioliasis vector Lymnaea diaphana and phylogenetic analysis of the genus Pectinidens (Gastropoda)
}

\author{
Maria Dolores Bargues ${ }^{1 /+}$, Roberto Luis Mera y Sierra² ${ }^{2}$ Patricio Artigas ${ }^{1}$, Santiago Mas-Coma ${ }^{1}$ \\ 'Departamento de Parasitología, Facultad de Farmacia, Universidad de Valencia, \\ Av. Vicente Andrés Estellés s/n, 46100 Burjassot, Valencia, Spain ${ }^{2}$ Cátedra de Parasitología y Enfermedades Parasitarias, \\ Facultad de Ciencias Veterinarias, Universidad Juan Agustín Maza, Guaymallén, Mendoza, Argentina
}

Freshwater lymnaeid snails are crucial in defining transmission and epidemiology of fascioliasis. In South America, human endemic areas are related to high altitudes in Andean regions. The species Lymnaea diaphana has, however, been involved in low altitude areas of Chile, Argentina and Peru where human infection also occurs. Complete nuclear ribosomal DNA 18S, internal transcribed spacer (ITS)-2 and ITS-1 and fragments of mitochondrial DNA $16 S$ and cytochrome c oxidase (cox)1 genes of L. diaphana specimens from its type locality offered 1,848, 495, 520, 424 and 672 bp long sequences. Comparisons with New and Old World Galba/Fossaria, Palaearctic stagnicolines, Nearctic stagnicolines, Old World Radix and Pseudosuccinea allowed to conclude that (i) L. diaphana shows sequences very different from all other lymnaeids, (ii) each marker allows its differentiation, except cox 1 amino acid sequence, and (iii) L. diaphana is not a fossarine lymnaeid, but rather an archaic relict form derived from the oldest North American stagnicoline ancestors. Phylogeny and large genetic distances support the genus Pectinidens as the first stagnicoline representative in the southern hemisphere, including colonization of extreme world regions, as most southern Patagonia, long time ago. The phylogenetic link of $\mathrm{L}$. diaphana with the stagnicoline group may give light to the aforementioned peculiar low altitude epidemiological scenario of fascioliasis.

Key words: Lymnaea diaphana - Lymnaeidae - nuclear rDNA - mtDNA - phylogeny - fascioliasis vectors

Freshwater snails of the family Lymnaeidae are of great importance in public health due to their capacity to transmit fascioliasis, a parasitic disease caused by the two liver fluke species Fasciola hepatica and Fasciola gigantica (Mas-Coma et al. 2009a). Whereas the consequences of fascioliasis are the cause of concern in livestock husbandry since long ago (Spithill et al. 1999, Torgerson \& Claxton 1999), its impact on human communities has shown to progressively increase from an amount of 2,500 human cases in 1990 (Chen \& Mott 1990) to a global estimation of 17 million people affected which may be even worse if the lack of knowledge in many regions of Africa and Asia are considered (MasComa et al. 2009a). This recent emergence appears to be at least in part related to climate change (Mas-Coma et al. 2008, 2009b). General concern about fascioliasis has moreover risen due to the large long-term pathogenicity of fasciolid flukes (Valero et al. 2003, 2006, 2008) and their immunosuppression effect (Gironés et al. 2007)

Financial support: SAF2006-09278, SAF2010-20805 (MICINN, Spain), PI030545, RD06/0021/0017 (RICET, FIS, Spain), RLA5049 (AIEA, Austria), Secretaría de Ciencia, Técnica y Posgrado, UNCU, Area de Investigación, UMAZA, Argentina

The aim of this study is included within the worldwide initiative of WHO (Headquarters Geneva, Switzerland) against human fascioliasis. + Corresponding author: m.d.bargues@uv.es

Received 12 May 2011

Accepted 19 July 2011 recently demonstrated in the advanced chronic stage of the disease, which appears to be the usual situation of infected subjects in the human endemic areas.

Within the several human fascioliasis hotspot regions known, South America is characterized by the so-called Andean transmission pattern, including the Altiplano subpattern and Valley subpattern. Both subpatterns are characterized by high altitude endemic areas, including high prevalences and intensities in humans caused by $F$. hepatica, such as in Bolivia (Hillyer et al. 1992, Esteban et al. 1997a, b, 1999) and Peru (Esteban et al. 2002, Gonzalez et al. 2011). In Argentina the human fascioliasis situation, although underestimated, also shows a link to altitude areas (Mera y Sierra et al. 2011). However, human infection in South America has also been described to be relatively frequent in given low altitude areas, such as in Arequipa region, Peru and southern Chile, where the species Lymnaea diaphana King, 1830 has been noted to be directly involved in the transmission (Cordova et al. 1961, Tantalean et al. 1974, Larrea et al. 1994) or known to be present in the transmission area (Sielfeld 2001, Valdovinos 2006), respectively. Additionally, L. diaphana is known to inhabit the southernmost areas of South America (Hubendick 1951) where animal fascioliasis has been described, in both Chile (Alcaino \& Apt 1989, Morales et al. 2000) and Argentina (Olaechea 1994).

In spite of their applied interest, our knowledge on lymnaeid snails is far from sufficient regarding both their genetics and their vector role. This situation is well illustrated by the systematic-taxonomic controversy in which this molluscan family is immersed (see review in 
Bargues et al. 2001). At lymnaeid species level, the problems are mainly due to the interspecific morphological and anatomic uniformity numerous species show, usually presenting serious difficulties in specimen classification, sometimes even impeding it. Moreover, intraspecific variation of shell shape is particularly well marked within lymnaeids depending on environmental conditions, although a genetic component in shell shape has been shown at least in some lymnaeid populations (Samadi et al. 2000). In the Americas, there are many specimen classification problems, mainly concerning fascioliasis vector species of the so-called "fossarine" or Galba/Fossaria group (Bargues et al. 2007), which is characterized by a shell shape and size range within which L. diaphana fits (Paraense 1984).

Recent studies have shown that nuclear ribosomal DNA (rDNA) and mitochondrial DNA (mtDNA) sequences furnish appropriate markers to clarify the systematics of this snail group as well as lymnaeid specimen classification even in particularly confusing lymnaeid groups (Bargues \& Mas-Coma 1997, 2005, Bargues et al. 1997, 2001, 2003, 2006, 2007, Remigio \& Blair 1997a, b, Remigio 2002, Remigio \& Hebert 2003). Additionally, analyses have recently shown that the only way to perform a correct, definitive species ascription to a DNA sequence is by comparing with the sequence of the same marker obtained in specimens collected in the type locality of the species (Bargues et al. 2011a), as already followed concerning shell and morphoanatomical characteristics by Paraense $(1976,1984)$.

The current trend in molecular population genetics is to use increasing numbers of genes in the analysis. Here we describe a multigenic sequence analyses of L. diapha$n a$ thanks to the attainment of complete sequences of the $18 \mathrm{~S}$ gene and the first and second internal transcribed spacers (ITS), ITS-1 and ITS-2, of the rDNA and partial sequences of the $16 \mathrm{~S}$ gene and cytochrome $\mathrm{c}$ oxidase subunit I (coxl) coding gene. To avoid any possible doubt, the molecular characterization is based only on specimens collected in the type locality of this species. These sequences are analyzed in full detail, by means of pairwise comparisons and phylogenetic methods, with those of the same markers in (i) other American lymnaeid species of the "fossarine" or Galba/Fossaria group, most of them represented by specimens from the respective type localities of the species, (ii) the main fascioliasis vector species throughout the world Galba truncatula, which also belongs to the Galba/Fossaria group and (iii) morphologically close Nearctic and Palaearctic species of the "stagnicoline" group. Finally, the study is also used for the analysis of the lymnaeid genus Pectinidens, which was proposed with $L$. diaphana as type species long ago (Pilsbry 1911). Pectinidens has also been used at subgenus level to even include other Galba/Fossaria vector species such as Lymnaea viatrix (Alcaino \& Apt 1989).

\section{MATERIALS AND METHODS}

Lymnaeid snail materials - The snail specimens studied were collected in the field, at the type locality included in the original description of the species L. diaphana: neighbourhood of Cape Gregory, which is on the continental side of the eastern end of the Strait of Magalhaens, province of Magallanes, Chile (King \& Broderip 1832, Pilsbry 1911, Paraense 1984). For a complete description of the shell and anatomy of topotypic specimens of this species, including detailed drawings, see Paraense (1984). A typic specimen of the lymnaeid snails collected is illustrated in Fig. 1. The terra typica of this lymnaeid (S52 $37^{\prime} 52.3^{\prime \prime}$ W70 $10^{\circ} 18.0^{\prime \prime}$, altitude 2-5 m) is constituted by different neighbouring water collections resulting from subsoil effluences in a wide area of sheep farming (see kind of biotopes in Fig. 2A, B). Specimens were usually found inside cold water, mostly on stony waterbottom (Fig. 2C) and only very rarely outside water as on floating leafs (Fig. 2D). No other lymnaeid species was found in the water collections studied.

Molecular techniques - DNA was only isolated from the foot of each alcohol-fixed snail (Bargues et al. 1997, 2007). Total DNA was isolated according to the phenol-chloroform extraction and ethanol precipitation method. The procedure steps were performed according to methods outlined previously (Bargues \& Mas-Coma 1997, Bargues et al. 2001, 2007). The pellet was dried and resuspended in $30 \mu \mathrm{L}$ sterile tris-ethylenediamine tetraacetic acid (TE) buffer ( $\mathrm{pH}$ 8.0). This suspension was stored at $-20^{\circ} \mathrm{C}$ until use.

A combined set of nuclear rDNA and mtDNA markers were polymerase chain reaction (PCR) amplified independently for each lymnaeid specimen and each PCR product was sequenced for a bona-fide haplotype characterization. The complete 18S rRNA gene was amplified using specific primers (Bargues et al. 1997, 2011a). The rDNA spacers ITS-2 and ITS-1 were amplified using primers designed in conserved positions of $5.8 \mathrm{~S}$ and 28S rRNA genes and $18 \mathrm{~S}$ and 5.8S rRNA genes, respectively (Bargues et al. 2001, 2006, 2007). The target $16 \mathrm{~S}$ gene region was amplified using a set of universal primers (Simon et al. 1991). Amplification procedures and thermal cycler conditions were carried out as previously described for lymnaeids (Remigio \& Blair 1997a). A coxl gene fragment was amplified using other universal primers (Folmer et al. 1994). Amplifications were generated in a Mastercycle ep gradient (Eppendorf, Hamburg, Germany) using specific PCR conditions for each marker, as previously described (Bargues et al. 2011a). Ten microlitres of each PCR product were checked by

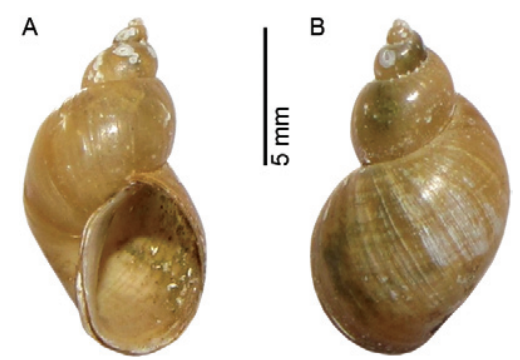

Fig. 1: specimen of Lymnaea diaphana collected at its type locality of Cape Gregory, Strait of Magellan, province of Magallanes. Chile. A: ventral view; $B$ : dorsal view. 
staining with ethidium bromide on $1 \%$ Nusieve ${ }^{\circledR}$ Genetic Technology Grade agarose (FMC Bioproducts) gel electrophoresis using the Molecular Weight Marker VI (Boehringer Mannheim) at $0.1 \mu \mathrm{g} \mathrm{DNA} / \mu \mathrm{L}$ as control.

Primers and nucleotides were removed from PCR products by purification on WizardTM PCR Preps DNA Purification System (Promega, Madison, WI, USA), according to the manufacturer's protocol, and suspended in $50 \mu \mathrm{L}$ of $10 \mathrm{mM}$ TE buffer ( $\mathrm{pH}$ 7.6). The final DNA concentration was determined by measuring the absorbance at 260 and $280 \mathrm{~nm}$.

DNA sequencing was performed on both strands by the dideoxy chain-termination method (Sanger et al. 1977). It was carried out with the Taq dye-terminator chemistry kit for ABI 3730 DNA Analyzer (Applied Biosystems, Foster City, CA, USA), using PCR primers. Sequences were aligned using CLUSTALW version 1.8 (Thompson et al. 1994) and MEGA 5.0 (Tamura et al. 2011). Minor corrections were manually introduced for a better fit of nucleotide correspondences in microsatellite sequence regions.

For 18S rRNA secondary structure representation, the previously published secondary structure prediction for Limicolaria kambeul 18S rRNA (Winnepennickx et al. 1992) based on the general eukaryote 18S rRNA secondary structure (De Rijk et al. 1992) was used and extended to encompass lymnaeid sequences.
DNA haplotype nomenclature - The codes for the sequences obtained follow the standard nomenclature proposed for lymnaeid snails previously (Bargues \& Mas-Coma 2005, Bargues et al. 2006, Mas-Coma et al. 2009a). It shall be noted that haplotype codes are only definitive in the case of complete sequences. When dealing with fragments or incomplete sequences, haplotype codes are provisional.

Sequence comparisons - The following sequences from GenBank and European Molecular Biology Laboratory $(\mathrm{EMBL})$ have been used for comparison and/or phylogenetic analyses: (i) $18 \mathrm{~S}$ rRNA gene: complete sequences of Lymnaea (Lymnaea) stagnalis (GenBank accession Z73984), Lymnaea (Stagnicola) palustris (Z73983), Omphiscola glabra (Z73982) and G. truncatula (Z73985) (Bargues \& Mas-Coma 1997), Lymnaea cubensis (Z83831) (Bargues et al. 1997, 2007), L. viatrix and Lymnaea neotropica (both species with the same sequence AM412222) (Bargues et al. 2007), Lymnaea humilis (FN182190) (Bargues et al. 2011a) and Pseudosuccinea columella (FN598152) (Bargues et al. 2011b), Radix auricularia (Z73980) and Radix balthica (Z73981) (Bargues \& Mas-Coma 1997, Bargues et al. 1997). Other lymnaeid incomplete sequences available in the GenBank have not been used to avoid problems in comparative sequence analyses. The planorbids Biomphalaria glabrata
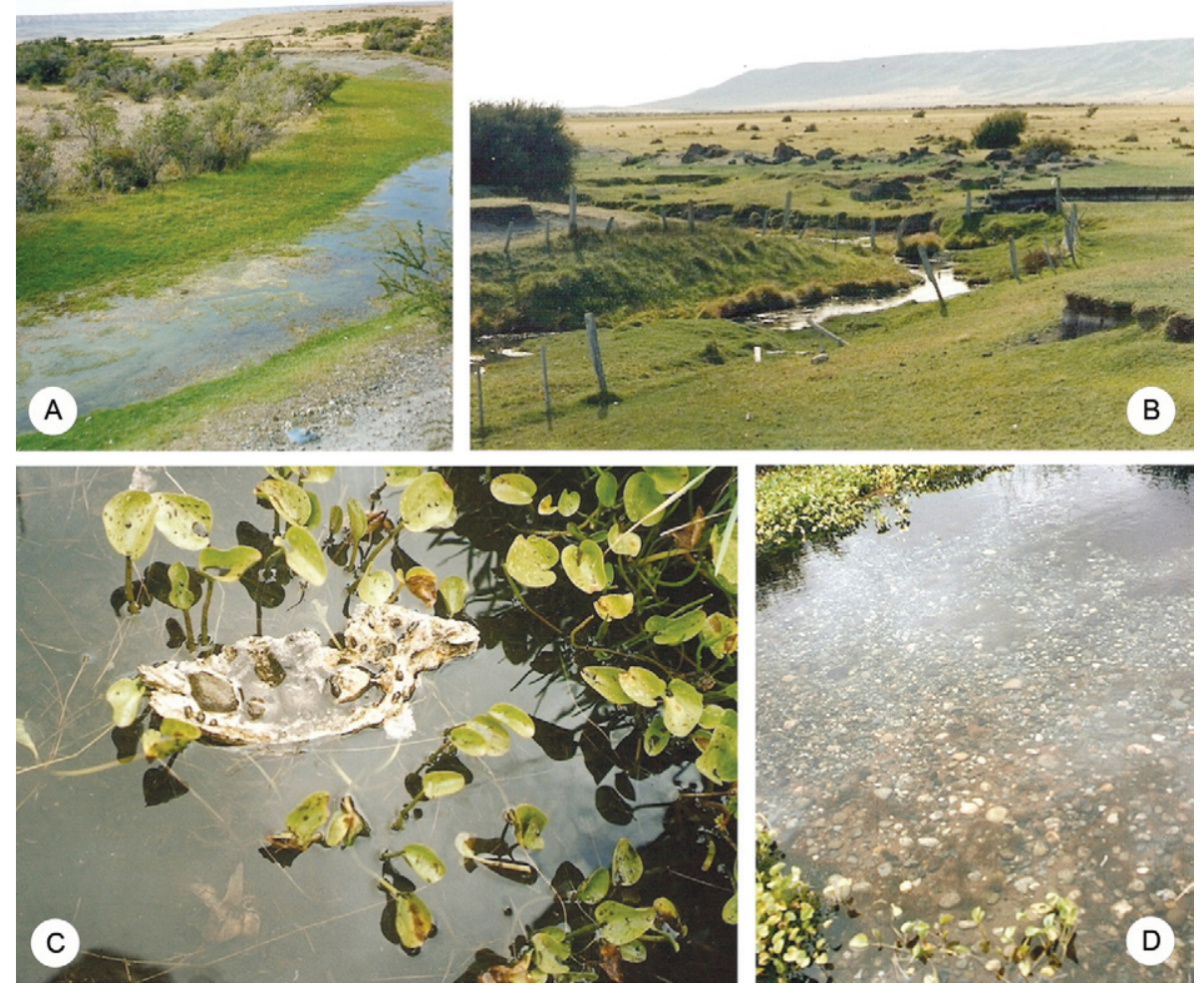

Fig. 2: type locality of Lymnaea diaphana at San Gregorio, Strait of Magellan, province of Magallanes. Chile: A: water collection inhabited by the species in a view to the Strait (see sea on the background); B: another water collection inhabited by the species in a view to the inland; C: specimens rarely found out of water, on a floating leaf; D: stony water ground on which specimens were usually found. 
(Hanelt et al. 1997) and Bulinus truncatus (Jorgensen et al. 2011) were included for comparison purposes; (ii) rDNA ITS-2: L. (S.) palustris palustris (AJ319620), Lymnaea (Stagnicola) fuscus (AJ319621) and Catascopia occulta (AJ319642) (Bargues et al. 2001, 2003), Catascopia catascopium (AF013143), Catascopia emarginata (AF013141, AF013142), Catascopia elodes (AF013138) and Hinkleyia caperata (AF013139) (Remigio \& Blair 1997b), G. truncatula H1 (AJ296271) (Bargues et al. 2001, Mas-Coma et al. 2001), L. cubensis H1 (AM412223) and H2 (FN182200) (Bargues et al. 2007, 2011a), L. viatrix H1 (AM412224) and L. neotropica H1 (AM412225) (Bargues et al. 2007), L. humilis H1 (FN182191) (Bargues et al. 2011a), P. columella H1 (FN598155) (Bargues et al. 2011b), R. auricularia (AJ319628) and R. balthica (AJ319633) (Bargues et al. 2001); (iii) rDNA ITS-1: L. (S.) palustris palustris (AJ626849), L. (S.) fuscus (AJ626856) and C. occulta (AJ626858) (Bargues et al. 2006), C. catascopium (AF013143), C. emarginata (AF013142), C. elodes (AF013138) and H. caperata (AF013139) (Remigio \& Blair 1997b), G. truncatula HA (AJ243018) (MasComa et al. 2001), L. cubensis HA (AM412226) and HB (FN182202) (Bargues et al. 2007, 2011a), L. viatrix HA (AM412227) and L. neotropica HA (AM412228) (Bargues et al. 2007), L. humilis HA (FN182193) (Bargues et al. 2011a), P. columella HA (FN598160) (Bargues et al. 2011b); R. auricularia (JF922878) and R. balthica (JF922879) (Bargues et al. 2011b); (iv) 16S rRNA gene of the mtDNA: Fossaria bulimoides (AF485657), Fossaria obrussa (AF485658) and Stagnicola bonnevillensis (AF485655) (Remigio 2002), F. bulimoides (EU038315) and Stagnicola elodes isolate 44106 (EU038305) (Wethington \& Lydeard 2007), L. humilis (FN182195) and L. cubensis (FN182204) (Bargues et al. 2011a), P. columella (PCU82073) (Remigio \& Blair 1997a); (v) mtDNA cox1 gene: S. elodes (AY227368), F. bulimoides (AY227367) and Austropeplea tomentosa (AY227365) (Remigio \& Hebert 2003), G. truncatula from Spain (AM494011) (Bargues et al. 2007) and Germany (EU818799) (Albrecht et al. 2008), L. cubensis coxla (AM494009) and coxlb (FN182205), L. neotropica coxla (AM494008) and cox $1 \mathrm{~b}$ (FN356741), L. humilis coxla, cox $1 \mathrm{~b}$ and coxlc (FN182197-9) (Bargues et al. 2007, 2011a, Mera y Sierra et al. 2009), P. columella (FN598165) (Bargues et al. 2011b) and P. columella (AY227366) (Remigio \& Hebert 2003), Radix rubiginosa (GU451737) (Liu et al. 2010).

Phylogenetic inference - Phylogenetic analysis of ITS- 1 and ITS- 2 combined haplotypes was firstly performed with a maximum likelihood (ML) approach using Phylogenetic Analysis Using Parsimony (PAUP) version 4.0b10 (Swofford 2002) and the PhyML program version 3.0 aLRT. ML parameters and the evolutionary model best fitting our dataset were determined using Akaike and Bayesian information criteria (Akaike 1974, Posada \& Buckley 2004), implemented in jModeltest version 0.1.1 (Posada 2008). Starting branch lengths were obtained using the least-squares method with ML distances. The intergenic region sequence (AY030361) (De Jong et al. 2001) including both ITSs of a planorbid species, Biomphalaria pfeifferi, was used as outgroup.
To provide an assessment of the reliability of the nodes in the ML tree, four methods were used. First, a distance-based phylogeny using the neighbour-joining (NJ) algorithm (Saitou \& Nei 1987) with the ML pairwise distances was obtained and statistical support for the nodes was evaluated with 1,000 bootstrap replicates, with and without removal of gapped positions, in PAUP. Second, a bootstrap analysis using 1,000 replicates was made by using branch-swapping algorithm (tree-bisection-reconnection) with full heuristic search in PAUP. Third, a Bayesian phylogeny reconstruction procedure was applied to obtain posterior probabilities (BPP) for the nodes in the ML tree, by using the same evolutionary model as above, implemented in MrBayes 3.1 (Ronquist \& Huelsenbeck 2003) with four chains during 1,000,000 generations and trees being sampled every 100 generations. The first 1,000 trees sampled were discarded ("burn-in") and clade posterior probabilities were computed from the remaining trees. Fourth, reliability for internal branch was assessed with a fast method using the aLRT test (SH-like) implemented in PhyML for final comparison purposes.

\section{RESULTS}

DNA sequences - Nuclear rDNA 18S, ITS-2 and ITS-1 and mtDNA $16 \mathrm{~S}$ and cox 1 nucleotide sequence data reported in this paper are available in the GenBank ${ }^{\mathrm{TM}}$, EMBL and DNA Data Bank of Japan databases under the accessions noted in Table I.

18S rRNA gene - The 18S rDNA sequences obtained in the $L$. diaphana specimens analyzed from the type locality are identical base to base, with a length of $1,848 \mathrm{bp}$ and a guanine-cytosine (GC) content of $51.68 \%$ (Table I).

A multiple sequence alignment of 11 different $18 \mathrm{~S}$ sequences, including several Galba/Fossaria vector species such as $L$. cubensis, L. viatrix (with $18 \mathrm{~S}$ sequence identical to that of L. neotropica), G. truncatula and L. humilis, the peculiar species $P$. columella, three representatives of stagnicolines such as $L$. (L.) stagnalis, $L$. (S.) palustris and $O$. glabra and two species of the Radix group such as $R$. auricularia and $R$. balthica, was 1,867 bp long, show-

TABLE I

Nuclear ribosomal DNA (rDNA) and mitochondrial DNA (mtDNA) barcode haplotype identification and respective GenBank accessions for the lymnaeid species Lymnaea diaphana from its type locality

\begin{tabular}{lcc}
\hline DNA marker & Haplotype code & Accession \\
\hline 18S rRNA & L.dia 18S-H1 & JF909497 \\
rDNA ITS-2 & L.dia ITS2-H1 & JF909498 \\
rDNA ITS-1 & L.dia ITS2-HA & JF909499 \\
mtDNA 16S & L.dia 16S-HA ${ }^{a}$ & JF909500 \\
mtDNA cox1 & L.dia cox1-Ha ${ }^{a}$ & JF909501 \\
\hline
\end{tabular}

$a$ : mtDNA haplotype codes only preliminary due to incomplete gene sequence. $\mathrm{H}$ : haplotypes. 
ing a total of 62 variable positions $(3.32 \%$ nucleotide divergence). Thirty of these 62 polymorphic sites appear grouped in the short sequence between positions 233 and 266, which corresponds to the helix E10-1 of the variable area V2 of the secondary structure (Supplementary data). Pairwise nucleotide differences at the level of the $18 \mathrm{~S}$ between $L$. diaphana and the other 10 aforementioned lymnaeid species, as well as with representatives of Planorbidae to comparatively assess distances at family level, are shown in Table II.

rDNA ITS-2 - Specimens of L. diaphana from the type locality present a 495 bp-long ITS-2, with a $56.97 \%$ GC content, which has been ascribed to L. diaphana haplotype 1 (L.dia ITS2-H1) (Table I).

Worth mentioning is the very high number of nucleotide differences detected in the pairwise comparisons of this ITS-2 sequence of L. diaphana with the ITS-2 of other European and American Galba/Fossaria, stagnicolines and Pseudosuccinea species available in GenBank. The ITS-2 dataset distance matrix obtained with PAUP shows that the number of total and mean character differences between $L$. diaphana and the other species considered are considerably high in all cases (Table III). These total differences ranged between 68-116 (average 88.6), when comparing with Galba/Fossaria species, and between 105-108 (average 106.5) and 66-80 (71.5), when L. diaphana is compared with European and American stagnicolines, respectively. Regarding $P$. columella, the differences are 81 (Table IV). According to these ITS-2 pairwise distance results, the group of species appearing to be more close to L. diaphana is the one of the American stagnicolines. Genetic distances between $L$. diaphana and its molecularly closest lymnaeid species according to PAUP (L. neotropica, C. catascopium, $C$. elodes and H. caperata) are shown in Table V.

rDNA ITS-1 - L. diaphana specimens collected in the type locality present an ITS-1 with a length of 520 bp and a GC content of $54.05 \%$. This ITS-1 sequence has been ascribed to L. diaphana haplotype A (L.dia ITS1-HA) (Table I).

Similarly as in the case of ITS-2, a very high number of nucleotide differences appear in the pairwise comparisons of this ITS-1 sequence of $L$. diaphana with the ITS-1 of species of Galba/Fossaria and stagnicolines, as well as to $P$. columella available in GenBank. The ITS-1 dataset distance matrix obtained with PAUP shows that the number of total and mean character differences between $L$. diaphana and the other species considered are considerably high in all cases (Table VI). These total differences ranged between 73-95 (average 85.6) when comparing with Galba/Fossaria species and between 100-101 (100.5) and 76-93 (86.7) when L. diaphana is compared with European and American stagnicolines, respectively. Regarding P. columella, a total of 105 differences appear (Table IV). According to these ITS-1 pairwise distance results and similarly as detected in the ITS-2 analysis, the group of lymnaeids appearing to be more close to $L$. diaphana is the one of the American stagnicolines. Genetic distances between $L$. diaphana and its molecularly closest lymnaeid species according to PAUP (G. truncatula and $H$. caperata) are shown in Table V.
$16 S m t D N A$ - Snail specimens from the type locality furnished a $16 \mathrm{~S}$ fragment sequence of a length of $424 \mathrm{bp}$ characterized by a considerable adenine-thymine (AT) biased average nucleotide composition of $70.75 \%$. The provisional code L.dia 16S-HA has been assigned for this fragment (Table I).

Estimates of evolutionary divergence and base composition bias differences in the $16 \mathrm{~S}$ sequence alignment including $L$. diaphana and other species available in GenBank demonstrate that $L$. diaphana is different from any other species of Galba/Fossaria and stagnicolines, as well as from $P$. columella, at the level of this mtDNA gene (Table VII, Supplementary data). In pairwise comparisons, minimum differences were 31 mutations when $L$. diaphana is compared with $S$. bonnevillensis and a maximum of 46 mutations appeared with $F$. bulimoides. Nucleotide differences were numerous and very similar when comparing L. diaphana with Galba/Fossaria (41-46, average 42.0), with stagnicolines $(31-41,36.0)$ and with $P$. columella (42) (Table VII). The eight species 445-bp-long alignment shows a total of 108 polymorphic sites, including 89 variable positions $(20 \%)$, of which 43 were parsimony informative ( $\mathrm{p}$-info), 46 were singleton sites and 19 gapped or ambiguous sites (Supplementary data). These variable positions do not appear regularly distributed throughout the 16S fragment and show evident concentrations in given hot spot regions (Supplementary data).

mtDNA coxl - The code L.dia coxl-Ha has been ascribed for the provisional haplotype obtained for this fragment. The sequence in question is 672-bp long and shows a high AT-biased composition of $69.40 \%$ (Table I).

In a multiple 672-bp-long sequence alignment restricted to 17 sequences similar in nucleotide length, a total of 473 positions were conserved and 199 variable, comprising 166 p-info and 33 singleton sites (alignment not shown). When comparing the L. diaphana coxl sequence with these other proximal lymnaeid species, including species of the Galba/Fossaria group, stagnicolines such as $S$. elodes, $P$. columella and also species of the Radix group such as A. tomentosa and $R$. rubiginosa, available in GenBank, the high number of nucleotide differences appears evident in a pairwise cox 1 distance matrix (Table VIII).

The code L.dia COX1-HI has been assigned to the provisional haplotype represented by the 224-aa-long protein sequence of that coxl gene fragment (Table I). In the protein alignment comprising $L$. diaphana and the aforementioned species, a total of 213 positions appeared to be conserved and 11 were variable, including five $\mathrm{p}$-info and six singleton sites. A pairwise comparison showed a $100 \%$ identity between this L. diaphana haplotype coxl-a and L. neotropica cox $1-\mathrm{b}$ form Argentina and only one amino acid change $(\mathrm{S} / \mathrm{G})$ when compared with $F$. bulimoides, G. truncatula, L. cubensis and L. neotropica haplotype coxl-a (Table IX).

Phylogenetic analysis - The combination of the two ITS in a single data-set generated a robust tree, indicating phylogenetic accordance between the two spacers. The ML model best fitting this data-set was HKY $85+\mathrm{G}+\mathrm{I}$, using a ts/tv ratio of $1.32(\mathrm{kappa}=2.5975285)$, base fre- 


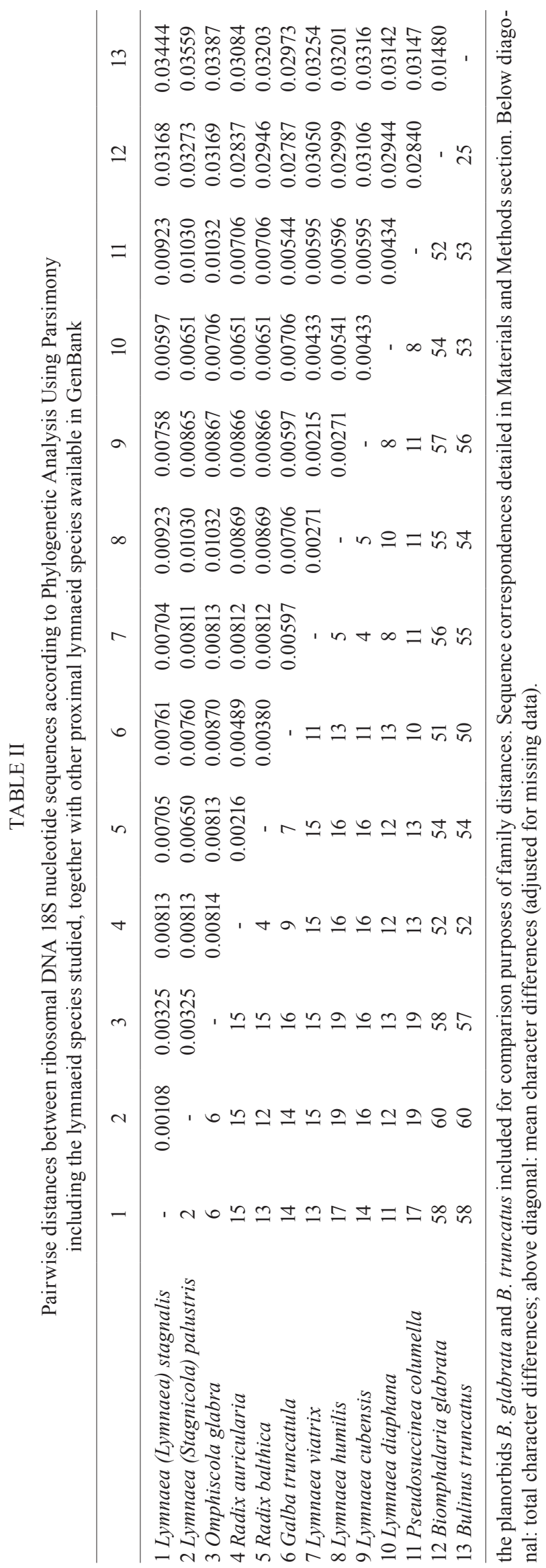

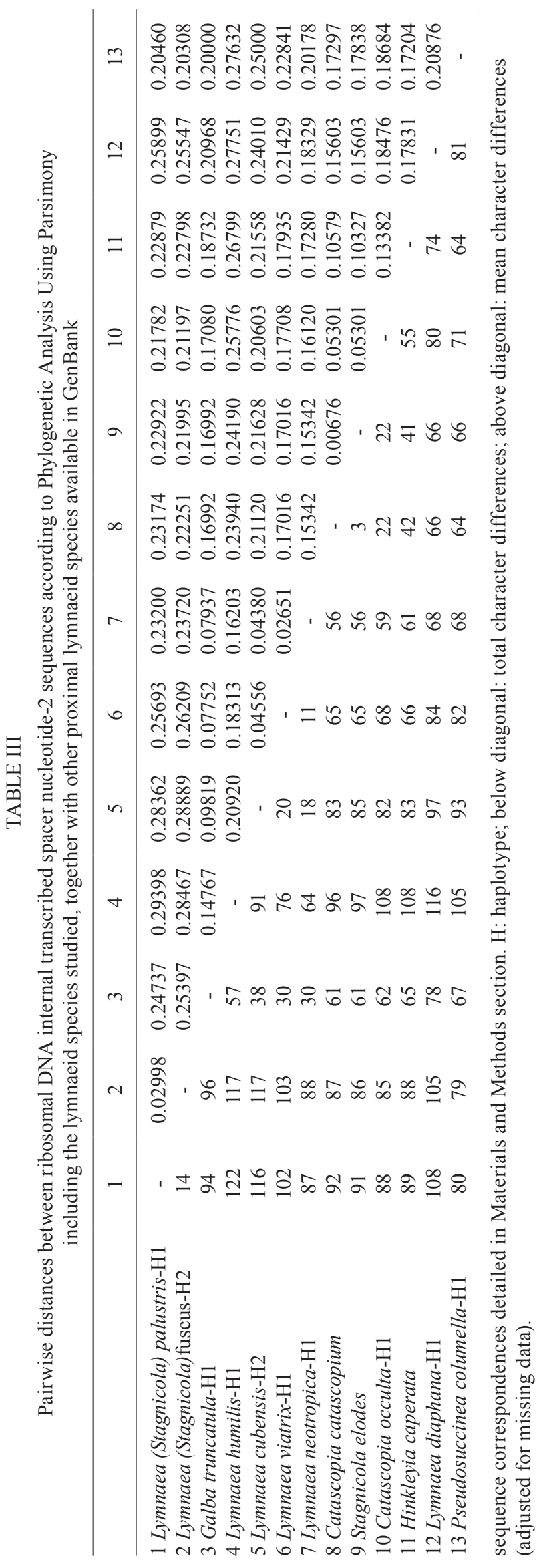


quencies for $\mathrm{A}, \mathrm{C}, \mathrm{G}$ and $\mathrm{T}$ of $0.22830,0.26280,0.22550$ and 0.28340 , respectively, gamma (continuous) with shape parameter alpha of 1.07 and a proportion of invariable sites equal to 0.121 (-ln L 9275.68103).

In the ML tree obtained (Fig. 3), the species of the Radix group appear clearly independent from all other lymnaeids, this independence always showing the highest support values. Worth emphasizing is also the presence of $P$. columella located basal to the branch, including species of both the Galba/Fossaria group and the stagnicolines, although such a location is not supported in the Heuristic analysis in which P. columella appears in a paraphyly regarding the fossarines and all stagnicolines nor in the Bayesian phylogeny reconstruction in which it appears basal to the Galbal Fossaria group (trees not shown).

In all trees obtained, European stagnicolines appear clustering together with the Galba/Fossaria group, whereas American stagnicolines (Hinkleyia and Catascopia, the latter also including the Palaearctic species $C$. occulta) appear separately, grouped within the same branch. L. diaphana appears basal to that clade comprising the American stagnicolines, with a bootstrap support of $74 \%, 76 \%$ and $88 \%$ with NJ, Heuristic and BPP algorithms, respectively. However, in the ML tree obtained with PhyML (tree not shown), the reliability for this L. diaphana - American stagnicolines cluster appear with a lower support of only $45 \%$ when applying the aLRT test.

\section{DISCUSSION}

Molecular characterization of L. diaphana - Phenotypically, this species was well described at the levels of both shell features and anatomical characteristics from specimens collected in the same type locality time ago (Paraense 1984).

Recently, broad analyses on the usefulness of the molecular markers offered by DNA in different organism groups have shown that nuclear rDNA correlates with the phenotype (shape, size, anatomy), while mtDNA does not (Mas-Coma \& Bargues 2009, Mas-Coma et al. 2009a), and that mtDNA poses many problems causing erroneous results when used to compare genetically distant taxa as distant species within the same genus or different genera (Lin \& Danforth 2004, Ballard \& Rand 2005, Mas-Coma \& Bargues 2009). This has obvious implications on the usefulness of these markers, as in fact traditional systematics and taxonomy, as those always applied to snails in malacology have fundamentally relied on morphology (Bargues et al. 2011a). Therefore, in Lymnaeidae it has been more recently concluded that (i) rDNA markers are the appropriate targets when dealing

\section{TABLE IV}

Total character differences (extreme and average values of nucleotide differences) at ribosomal DNA internal transcribed spacer (ITS)-2 and ITS-1 sequences according to Phylogenetic Analysis Using Parsimony in the pairwise distance comparisons between Lymnaea diaphana and the different lymnaeid groups studied

\begin{tabular}{lcccc}
\hline DNA marker & Galba/Fossaria group & European stagnicolines & American stagnicolines & Pseudosuccinea columella \\
\hline ITS-2 & $68-116(88.6)$ & $105-108(106.5)$ & $66-80(71.5)$ & $81(81)$ \\
ITS-1 & $73-95(85.6)$ & $100-101(100.5)$ & $76-93(86.7)$ & $105(105)$ \\
\hline
\end{tabular}

data set contains 736 and 765 characters for ITS-2 and ITS-1, respectively.

\section{TABLE V}

Genetic distances in internal transcribed spacer (ITS)-2 and ITS-1 detected in pairwise comparisons of Lymnaea diaphana with its molecularly closest lymnaeid species

\begin{tabular}{|c|c|c|c|c|c|}
\hline Pairwise sequence comparisons & $\begin{array}{l}\text { Alignment } \\
\text { length } \\
\text { (bp long) }\end{array}$ & $\begin{array}{l}\text { Conserved } \\
\text { positions } \\
\text { (n) }\end{array}$ & $\begin{array}{c}\text { Nucleotide } \\
\text { differences } \\
\mathrm{n}(\%)\end{array}$ & $\begin{array}{c}\text { Mutations } \\
\text { (transitions }+ \text { transversions) } \\
\mathrm{n}(\%)\end{array}$ & $\begin{array}{c}\text { Insertions }+ \text { deletions } \\
\text { (indels) } \\
\mathrm{n}(\%)\end{array}$ \\
\hline \multicolumn{6}{|l|}{ ITS-2 } \\
\hline L. diaphana vs. Lymnaea neotropica & 512 & 323 & $189(36.91)$ & $77(15.04)$ & $112(21.87)$ \\
\hline L. diaphana vs. Catascopia catascopium & 511 & 361 & $150(29.35)$ & $67(13.11)$ & $83(16.24)$ \\
\hline L. diaphana vs. Catascopia elodes & 499 & 340 & $159(31.86)$ & $104(20.84)$ & $55(11.02)$ \\
\hline L. diaphana vs. Hinkleyia caperata & 502 & 331 & $171(34.06)$ & $96(19.12)$ & 75 (14.94) \\
\hline \multicolumn{6}{|l|}{ ITS-1 } \\
\hline L. diaphana vs. Galba truncatula & 536 & 399 & $137(25.56)$ & $89(16.60)$ & $48(8.95)$ \\
\hline L. diaphana vs. Hinkleyia caperata & 591 & 427 & $164(27.75)$ & $89(15.01)$ & $75(12.69)$ \\
\hline
\end{tabular}




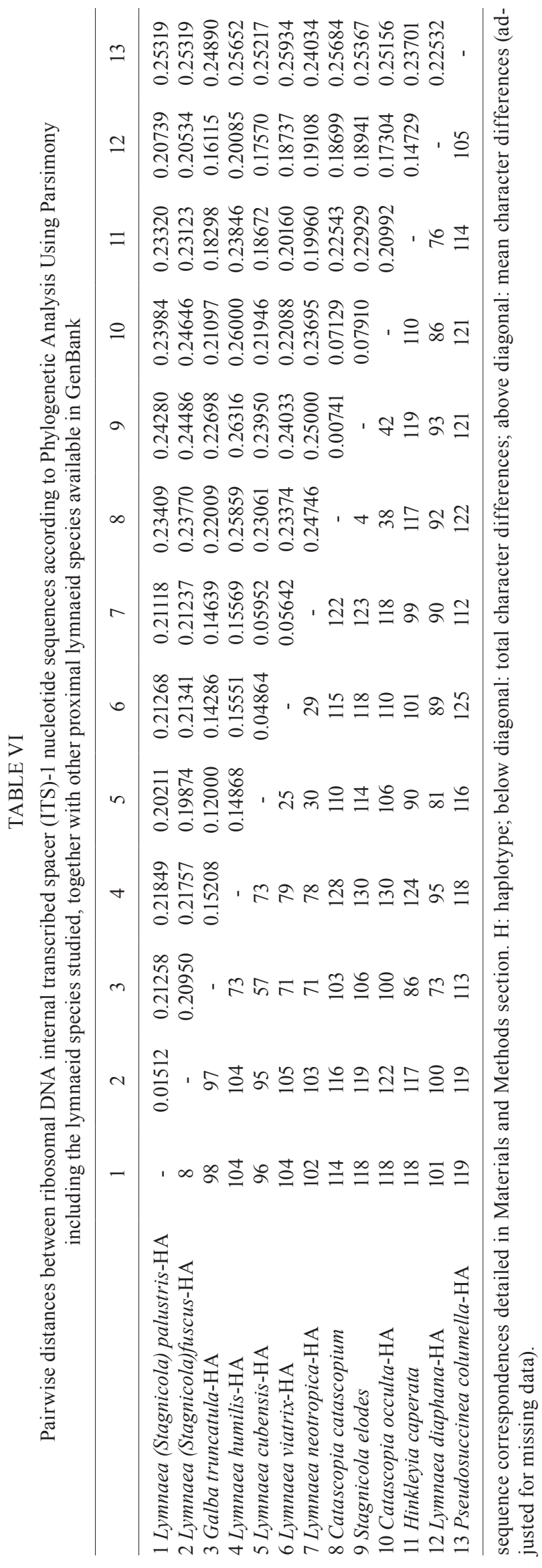

with systematic-taxonomic and phylogenetic aspects, as well as for molecular characterization of species by haplotyping, (ii) mtDNA markers are more convenient for population and intraspecific variability studies and (iii) both rDNA and mtDNA markers may be used for the classification of specimens (Bargues et al. 2011a).

The $18 \mathrm{~S}$ sequence of $L$. diaphana $(1848 \mathrm{bp})$ is slightly longer than that of $G$. truncatula $(1,843 \mathrm{bp}$ ) (Bargues et al. 1997), equally long than that of L. humilis (1,848 bp) (Bargues et al. 2011a), similar to that of the European stagnicolines L. stagnalis, O. glabra and L. (S.) palustris, the radicines $R$. auricularia and $R$. balthica, as well as to $P$. columella (ranging between 1,849-1,852 bp) (Bargues et al. 1997, 2011b), but pronouncedly shorter than that of L. cubensis, L. viatrix and L. neotropica (all three 1,860-bp long) (Bargues et al. 2007). This suggests that $L$. diaphana may be considered an old species within the family Lymnaeidae, according to their phylogeny in which the oldest lymnaeid fossil known is Galba from the Jurassic (Zilch 1959-1960, Inaba 1969), a shorter sequence would be the plesiomorphic condition and an increase in sequence length would have occurred during lymnaeid evolution (Bargues et al. 2001).

Pairwise nucleotide comparisons in a slowly evolving gene as the rRNA small subunit (Table II) show $L$. diaphana to be at a genetic distance from Old World radicines similar to that from Palaearctic stagnicolines, as well as from Galba. Only New World fossarines and Pseudosuccinea appear somewhat closer, suggesting a biogeographic background for such a relationship. Unfortunately, the $18 \mathrm{~S}$ sequence is not known for any Nearctic stagnicoline so far, in the way to verify an additional support for such an assumption.

With regard to the ITS-2, L. diaphana presents a sequence whose 495-bp length fits within the group of lymnaeids having the longest ITS-2 sequences (Bargues et al. 2001). This might be interpreted as a species having long time derived from the old form suggested by the $18 \mathrm{~S}$. In this context, L. diaphana shows evolutionary characteristics similar to the Nearctic species L. humilis (Bargues et al. 2011a). Additionally, the very high number of nucleotide differences it shows when compared to all other lymnaeid species (Table III) and groups (Table IV) is surprising. Moreover, contrary to what was expected, the distances regarding Nearctic stagnicolines appear to be lower than those regarding Holarctic Galba/Fossaria species (Table IV). This indicates that $L$. diaphana should not be included in the Galba/Fossaria group as its shell and anatomic characteristics suggest (Paraense 1984).

Such a relationship with American stagnicolines does, however, not appear so clear at ITS-1 level, a marker in which the lower L. diaphana differences appear with Old World originary G. truncatula (73) and North American H. caperata (76) (Table VI). Interestingly, the length of ITS-1 in L. diaphana is the shortest hitherto known in Lymnaeidae (520 bp), only surpassed by $G$. truncatula (504 bp).

Particular aspects of the results obtained in mtDNA 16S sequences should be highlighted: (i) AT composition appears to be pronouncedly biased, which should be taken into account when analyzing the significance of the 
information this marker offers, (ii) variable positions do not appear regularly distributed throughout the sequence, but concentrated in hot spot regions (Supplementary data), which indicates that the information furnished by the fragment may not appropriately reflect whole gene evolution, as already seen in other organisms (Mas-Coma \& Bargues 2009), and (iii) nucleotide differences appear to be less in number than those logically expected from mtDNA (Table VII), which suggests a low mutation rate indeed only apparent, as a consequence of an evolutionary parallelism of its rRNA gene function inside the mitochondrial genome with fast evolving mtDNA coding genes giving rise to position saturation, as already seen in lymnaeids and other freshwater molluscs (Bargues et al. 2011a). Thus, the somewhat closer $16 \mathrm{~S}$ sequence of $L$. diaphana to that of American stagnicolines, represented by S. bonnevillensis, may be considered with great caution.

Nucleotide saturation and biased composition may also pose a significance question mark on the potential relationships of $L$. diaphana with the different lymnaeid groups, as suggested by the high number of nucleotide differences in the mtDNA coxl gene (Table VIII). This mtDNA saturation problem has already been highlighted in lymnaeids very recently (Bargues et al. 2011a). Moreover, the very few amino acid differences in the protein sequence (Table IX) indicate that most of the nucleotide differences are silent. Additionally, there is unfortunately only one stagnicoline from which the cox 1 fragment in question is available (S. elodes), so that no conclusions may be obtained from that comparison.

Summing up, the following conclusions may be obtained from the sequence analyses of nuclear rDNA and mtDNA markers: (i) L. diaphana shows sequences very different from all hitherto lymnaeid sequences available at the level of both nuclear rDNA and mtDNA markers, (ii) each one of the five markers analyzed, including rDNA 18S, ITS-2 and ITS-1, as well as mtDNA $16 \mathrm{~S}$ and coxl, allow the differentiation of L. diaphana specimens from all other lymnaeids; only the COX1 amino acid sequence does not, (iii) nuclear rDNA suggest that $L$. diaphana is not a fossarine lymnaeid, but rather a relict form related to ancestral stagnicolines and (iv) mtDNA markers do not furnish genetic distance information useful for the analysis of the relationships of $L$. diaphana with the different lymnaeid groups.

Phylogenetic relationships and Pectinidens genus assessment - L. diaphana was selected as type species of the new section Pectinidens within the genus Lymnaea Lamarck by Pilsbry (1911). The erection of Pectinidens was justified on the characteristics of the radular teeth of $L . d i-$ aphana, noted to have peculiarities different from all other lymnaeids known at that time. Pectinidens was considered at genus level until its synonymization with Lymnaea by Hubendick (1951). From that moment, it disappeared from the lymnaeid literature, although a few authors still sporadically referred to it, whether at genus level (Inaba 1969) or at subgenus level (Alcaino \& Apt 1989).

In the phylogenetic reconstructions performed, $L$. diaphana does not cluster together with other morphologically similar fossarine lymnaeids as the New World L. cubensis, L. viatrix and L. neotropica, the Nearctic L. humilis, or the Old World G. truncatula. Contrary to what would be phenotypically expected, L. diaphana appears basal to the Nearctic stagnicolines (Fig. 3). Values supporting such a phylogenetic relationship were higher than $70 \%$ in most of the node reliability assessment methods. Although it may be argued that higher node supports would be better as to conclude that this result is definitive, the phylogenetic tree agrees with the very numerous nucleotide differences and very large genetic distances shown by DNA markers with verified usefulness at specific and supraspecific levels as both ITSs. Thus, in ITS-2 and ITS- 1 the nucleotide differences separating $L$. diaphana from all other lymnaeids appear to be of supraspecific level in both spacers (see Table

\section{TABLE VII}

Pairwise distances between mitochondrial DNA 16S ribosomal DNA gene data set nucleotide sequences according to Phylogenetic Analysis Using Parsimony including the lymnaeid species studied together with other proximal lymnaeid species available in GenBank

\begin{tabular}{|c|c|c|c|c|c|c|c|c|c|}
\hline & 1 & 2 & 3 & 4 & 5 & 6 & 7 & 8 & 9 \\
\hline 1 Lymnaea diaphana & - & 0.09762 & 0.09739 & 0.10072 & 0.09785 & 0.09927 & 0.09716 & 0.11005 & 0.07329 \\
\hline 2 Lymnaea humilis & 41 & - & 0.04276 & 0.10526 & 0.00000 & 0.00241 & 0.04976 & 0.08115 & 0.08789 \\
\hline 3 Lymnaea cubensis & 41 & 18 & - & 0.10048 & 0.04265 & 0.04589 & 0.01174 & 0.07619 & 0.08706 \\
\hline 4 Pseudosuccinea columella & 42 & 44 & 42 & - & 0.10526 & 0.10706 & 0.10263 & 0.10287 & 0.10476 \\
\hline 5 Stagnicola elodes & 41 & 0 & 18 & 44 & - & 0.00242 & 0.04965 & 0.07889 & 0.08768 \\
\hline 6 Fossaria obrussa & 41 & 1 & 19 & 44 & 1 & - & 0.05301 & 0.08495 & 0.09179 \\
\hline 7 Fossaria bulimoides ${ }^{a}$ & 41 & 21 & 5 & 43 & 21 & 22 & - & 0.07601 & 0.08216 \\
\hline 8 Fossaria bulimoides ${ }^{b}$ & 46 & 34 & 32 & 43 & 34 & 35 & 32 & - & 0.10214 \\
\hline 9 Stagnicola bonnevillensis & 31 & 37 & 37 & 44 & 37 & 38 & 35 & 43 & - \\
\hline
\end{tabular}

$a$ : AF485657; $b$ : EU038315. Sequence correspondences detailed in Materials and Methods section. H: haplotype; below diagonal: total character differences; above diagonal: mean character differences (adjusted for missing data). 


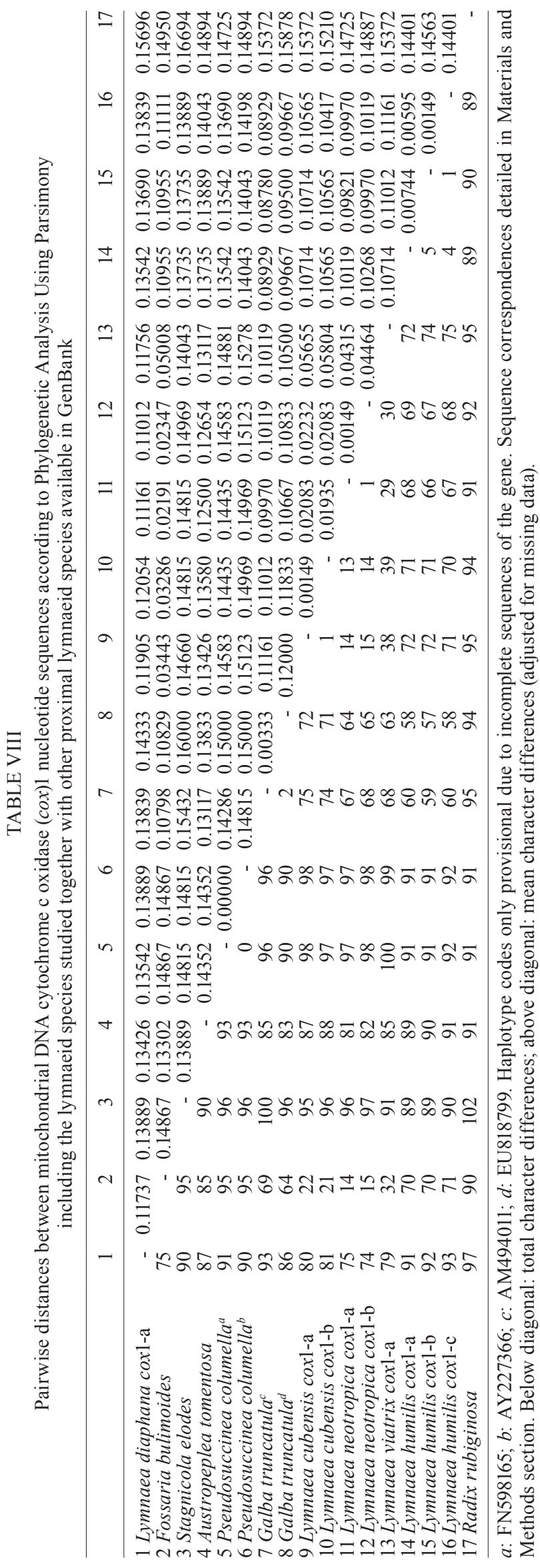

IV for p-info positions). A deep analysis of genetic distances between $L$. diaphana and its molecularly closest lymnaeid species belonging to the Nearctic stagnicoline group and the Galba/Fossaria group according to PAUP (Tables III, VI) shows very high values (ITS-2: 29.35$36.91 \%$; ITS-1: $25.56-27.75 \%$ ) of unquestionable genus level (Table V) when compared with known genetic distances between lymnaeid genera (Bargues et al. 2001, 2006). Consequently, taxonomic validity should be restored to the genus Pectinidens.

It should be added that, in the literature, L. diaphana has usually been ascribed to King, 1830. In the original article including the description of this species, both in the second page of the contents index and in page 332 at the beginning of the article 47, it is noted "By Captain Phillip P. King, R.N., F.R.S., \& c. assisted by W.J. Broderip, Esq. F.R.S., \& c". Moreover, although the issue 19 of The Zoological Journal corresponds, as clearly stated in the issue front cover, to the period of July 1830-September 1831, at the bottom of this front cover it is also noted "London: printed by... and Published by... 1832". Finally, different misunderstandings have appeared in the literature with regard to the original reference; the correct one should include Year 1832, Volume 5 (from 1832-1834), Issue 19 (July 1830-September 1831), article 47, species described within article list under 43 in page 344. Therefore, according to present rules, the correct type species taxon of Pectinidens would thus become Pectinidens diaphana (King \& Broderip, 1832) Pilsbry, 1911.

Stagnicolines are generally characterized by its elongate and pointed shell form, relatively long size, very numerous in species number, hitherto known to be restricted to the northern hemisphere and mostly lymnaeids adapted to live in cold waters (Bargues et al. 2003). The smaller size of only up to $14.6 \mathrm{~mm}$ long and $8.8 \mathrm{~mm}$ wide of five-whorl $L$. diaphana specimens (Paraense 1984) may be interpreted as not being sufficient as to manifest the typical stagnicoline elongate trend, similarly as has been recently shown in L. humilis (Bargues et al. 2011a). This would explain the usual including of $L$. diaphana within the Galba/Fossaria group. Inaba (1969) even considered Pectinidens as a form presumably derived at the beginning of the Pleistocene from Fossaria species characterized by harbouring 18 chromosomes. Accepting the ascription of $L$. diaphana to the stagnicoline group would, thus, represents not only its first representative in the southern hemisphere, but also the colonization of extreme world regions, as it is the case of the most southern Patagonia, by stagnicolines long time ago.

Whether such an old southward spreading phenomenon only concerned $L$. diaphana or additionally other lymnaeid species still remains an open question. In fact, the present molecular study furnishes the baseline on which to clarify the systematic/taxonomic validity of numerous lymnaeid species described in the southernmost mainland areas and islands of South America, in Chile as well as in Argentina. All of these species are very similar to $L$. diaphana and several of them have already been proposed to be synonyms of $L$. diaphana, although the opinion about the validity of particular species differ according to authors: Lymnaea lebruni Mabille 1883, Lymnaea falklandiana Smith, 1884, Lymnaea pictonica Rochebrune and 
Mabille, 1889, Lymnaea patagonica Strebel, 1907, Lymnaea brunneoflavida Preston, 1910, Lymnaea andeana Pilsbry, 1911, Lymnaea inelegans Pilsbry 1911, Lymnaea riochicoensis Pilsbry, 1911 and Lymnaea plicata Hylton Scott, 1954 (Rochebrune \& Mabille 1885, Pilsbry 1911, Hubendick 1951, Hylton Scott 1954, Malek 1985). Indeed, many of these lymnaeid species were already included within Pectinidens by Pilsbry (1911).

L. diaphana and fascioliasis transmission - With regard to epidemiological characteristics and transmission patterns in human fascioliasis endemic areas, its zoonotic aspect seems to have only a relative influence due mainly to the scarce differences related to different livestock species playing a role of reservoir, given the similar infectivity of the metacercarial stage from different livestock species isolates (Valero \& Mas-Coma 2000, Valero et al. 2001). On the contrary, its vectorborne aspect has proved to have a pronounced influence on human infection. The different fascioliasis patterns appear related to the different lymnaeid species, their ecology, type of water bodies they inhabit, their anthropophilic preferences, population dynamics, climatic links and transmission capacity (Bargues \& Mas-Coma 2005, Mas-Coma et al. 2009a).

\section{TABLE IX}

Cytochrome c oxidase (cox)1 amino acid sequence differences detected in pairwise comparisons between haplotypes of Lymnaea diaphana and other proximal lymnaeid species available in GenBank

\begin{tabular}{llll}
$\begin{array}{l}\text { Nucleotidic } \\
\text { haplotype } \\
\text { cox } 1\end{array}$ & $\begin{array}{l}\text { GenBank } \\
\text { accession }\end{array}$ & Country & $\begin{array}{l}\text { Variable } \\
\text { position }\end{array}$ \\
\hline
\end{tabular}

111112

1399902670

812689050664

\begin{tabular}{|c|c|c|c|}
\hline ia-cox $1-\mathrm{a}$ & JF909501 & Chile & I I T I L L C S PVS \\
\hline d & AY 22 & Canada & . G \\
\hline elodes & AY 22 & Canada &. VLV . . G \\
\hline nto. & AY2 & Australia & VM ...? S I T \\
\hline ella & $\mathrm{FN}$ & Vene & VVM ...G. $\ldots$ \\
\hline 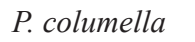 & AY & ia & VVM ...G. $\ldots$ \\
\hline & & $\mathrm{Sp}$ & $\ldots \ldots \mathrm{G}$ \\
\hline & & Ger & $\ldots \ldots G$ \\
\hline & $\mathrm{AM}$ & C & $\ldots . \mathrm{G}$ \\
\hline & & US & $\ldots \ldots \mathrm{G}$ \\
\hline & $\mathrm{AM}$ & 10 & $\ldots G$ \\
\hline & & Arge & $\ldots$ \\
\hline & $\mathrm{AM}$ & Arg &. $\mathrm{V} \ldots \mathrm{G}$ \\
\hline & $\mathrm{FN}$ & US &. $\mathrm{V} \ldots \mathrm{G}$ \\
\hline & $\mathrm{FN}$ & S &.$V \ldots G$ \\
\hline$x 1-\mathrm{c}$ & $\mathrm{FN} 1$ & USA &.$V \ldots G$ \\
\hline rubiginosa & GU451737 & hailand & . VS. F F VG \\
\hline
\end{tabular}

Fascioliasis endemic areas inhabited by $L$. diaphana are low altitude areas (Cordova et al. 1961, Tantalean et al. 1974, Larrea et al. 1994, Sielfeld 2001, Valdovinos 2006), which do not appear to fit the hitherto two main disease transmission scenarios where human infection epidemiology has been characterized: the Altiplano subpattern and Valley subpattern, both in high altitude endemic zones (Mas-Coma 2005, Mas-Coma et al. 2009a).

The phylogenetic link of $L$. diaphana with the stagnicoline group may give light to the aforementioned peculiar low altitude epidemiological scenario. Indeed, stagnicolines are only considered secondary vectors of fascioliasis when compared to the main vector species of $F$. hepatica included in the Galba/Fossaria group (Bargues et al. 2001) and to play an important transmission role only rarely in particular places where no other lymnaeid vector is present or under special natural conditions (Czapski 1962, 1997, Bouix-Busson \& Rondelaud 1985, 1986, Dreyfuss et al. 1994, 2000). The existence of lymnaeid species of high transmission capacity, belonging to the Galba/Fossaria group, has already been molecularly confirmed in low altitude endemic areas of Peru (Bargues et al. 2007). The participation of $L$. diaphana in disease transmission in the southernmost fascioliasis endemic areas of South America, in both Chile (Alcaino \& Apt 1989, Morales et

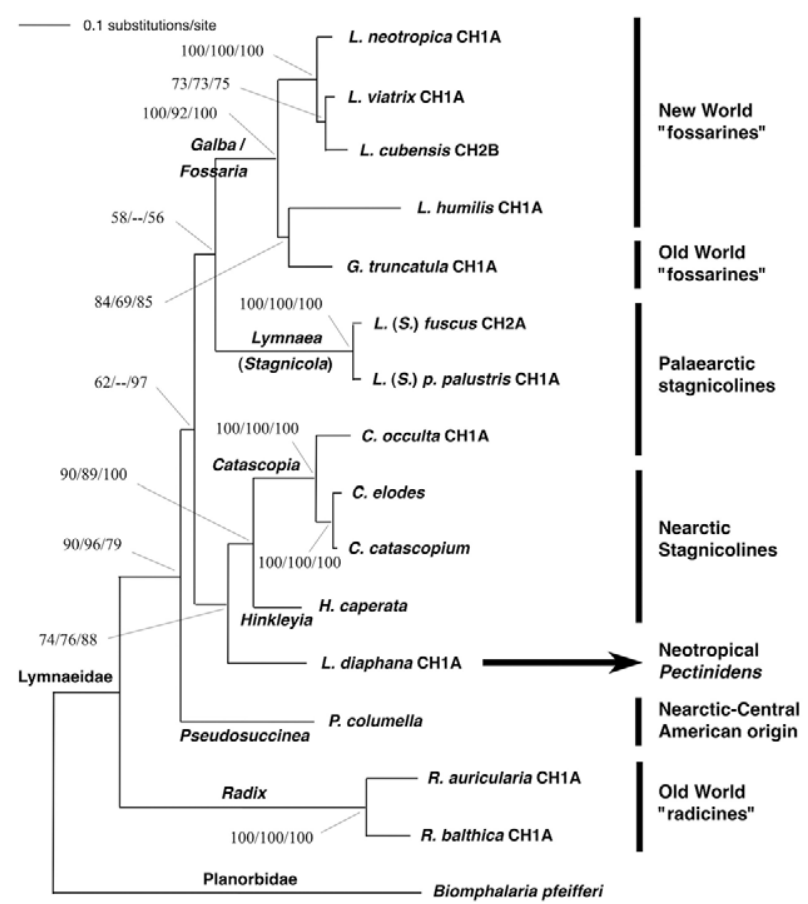

Fig. 3: phylogenetic tree of lymnaeid species studied obtained using the planorbid Biomphalaria pfeifferi as outgroup, based on maximumlikelihood (ML) estimates. CH: internal transcribed spacers composite haplotype. Scale bar indicates the number of substitutions per sequence position. Support for nodes $\mathrm{a} / \mathrm{b} / \mathrm{c}$ : $a$ : bootstrap with neighbour-joining reconstruction using Phylogenetic Analysis Using Parsimony (PAUP) with ML distance and 1,000 replicates; $b$ : bootstrap with ML reconstruction using PAUP with 1,000 heuristic replicates; $c$ : Bayesian posterior probability with ML model using MrBayes. 
al. 2000) and Argentina (Olaechea 1994), whether as only vector or coexisting with other lymnaeid vector species (e.g., L. viatrix) (Kaczorkiewick 1983, Rubel et al. 2005, Kleiman et al. 2007) should be assessed.

Molecular markers established in the present study furnish the needed baseline on which to (i) address the validity or synonymy of each one of the several aforementioned lymnaeid species cited in southern Patagonia, (ii) clarify the geographical distribution and intraspecific genetic variability of $L$. diaphana and finally (iii) assess its population dynamics correlation with fascioliasis transmission. The cold weather typical of such extreme latitudes suggest, in the southern low altitude Patagonian plains, a marked transmission seasonality restriction due to the minimum temperature $9-10^{\circ} \mathrm{C}$ threshold of $F$. hepatica (Fuentes et al. 1999, 2001). Such a seasonality has already been verified somewhat more northward in Andean valleys (Kleiman et al. 2007).

\section{ACKNOWLEDGEMENTS}

To Mr. Ricardo Vladilo Bartulovich, owner of the land where snail collections were made, for his valuable help, and to the Servicio Agricola Ganadero of Chile, through its office of Punta Arenas, for the useful information they provide.

\section{REFERENCES}

Akaike H 1974. A new look at the statistical model identification. Ieee Trans Automat Control 19: 716-723.

Albrecht C, Wolf C, Glöer P, Wilke T 2008. Concurrent evolution of ancient sister lakes and sister species: the freshwater gastropod genus Radix in lakes Ohrid and Prespa. Hydrobiologia 615: 157-167.

Alcaino H, Apt W 1989. Algunos antecedentes sobre la fascioliasis animal y humana. Monogr Med Vet 11: 14-29.

Ballard JWO, Rand DM 2005. The population biology of mitochondrial DNA and its phylogenetic implications. Ann Rev Ecol Evol Syst 36: 621-642.

Bargues MD, Artigas P, Khoubbane M, Flores R, Glöer P, RojasGarcia R, Ashrafi K, Falkner G, Mas-Coma S 2011a. Lymnaea schirazensis, an overlooked snail distorting fascioliasis data: genotype, phenotype, ecology, worldwide spread, susceptibility, applicability. PLOS ONE 6: e24567.

Bargues MD, Artigas P, Jackiewicz M, Pointier JP, Mas-Coma S 2006. Ribosomal DNA ITS-1 sequence analysis of European stagnicoline Lymnaeidae (Gastropoda). Heldia München 6: 29-40.

Bargues MD, Artigas P, Mera y Sierra RL, Pointier JP, Mas-Coma S 2007. Characterisation of Lymnaea cubensis, $L$. viatrix and $L$. neotropica n. sp., the main vectors of Fasciola hepatica in Latin America, by analysis of their ribosomal and mitochondrial DNA. Ann Trop Med Parasitol 101: 621-641.

Bargues MD, Gonzalez LC, Artigas P, Mas-Coma S 2011b. A new baseline for fascioliasis in Venezuela: lymnaeid vectors ascertained by DNA sequencing and analysis of their relationships with human and animal infection. Parasit Vectors 4: 200.

Bargues MD, Horak P, Patzner RA, Pointier JP, Jackiewicz M, MeierBrook C, Mas-Coma S 2003. Insights into the relationships of Palaearctic and Nearctic lymnaeids (Mollusca: Gastropoda) by rDNA ITS-2 sequencing and phylogeny of stagnicoline intermediate host species of Fasciola hepatica. Parasite 10: 243-255.

Bargues MD, Mangold AJ, Muñoz-Antolí C, Pointier JP, MasComa S 1997. SSU rDNA characterization of lymnaeid snails transmitting human fascioliasis in South and Central America. J Parasitol 83: 1086-1092.
Bargues MD, Mas-Coma S 1997. Phylogenetic analysis of lymnaeid snails based on 18S rDNA sequences. Mol Biol Evol 14: 569-577.

Bargues MD, Mas-Coma S 2005. Reviewing lymnaeid vectors of fascioliasis by ribosomal DNA sequence analyses. $J$ Helminthol 79: 257-267.

Bargues MD, Vigo M, Horak P, Dvorak, Patzner RA, Pointier JP, Jackiewicz M, Meier-Brook C, Mas-Coma S 2001. European Lymnaeidae (Mollusca: Gastropoda), intermediate hosts of trematodiases, based on nuclear ribosomal DNA ITS-2 sequences. Infect Genet Evol 1: 85-107.

Bouix-Busson D, Rondelaud D 1985. Etude de l'aptitude à l'infestation fasciolienne chez Lymnaea glabra Müller et chez L. truncatula dans des peuplements mono et bispécifiques. Bull Soc Fran Parasitol 33: 95-98.

Bouix-Busson D, Rondelaud D 1986. L'infestation de Lymnaea glabra Müller par Fasciola hepatica L. Etude expérimentale sur le terrain. Ann Parasitol Hum Comp 61: 215-225.

Cordova E, Naquira F, Naquira C 1961. Lymnaea diaphana King como huésped intermediario de Fasciola hepatica en Arequipa (Perú). Arch Per Patol Clin 15: 165-172.

Czapski Z 1962. The snail Galba occulta Jackiewicz, 1959, another intermediate host of Fasciola hepatica L. Z Tropenmed Parasitol 13: 332-337.

Czapski Z 1997. Biologiczne aspekty epidemiologii fasciolozy. Monog Podreczniki Skrpty AWF w Poznaniu 95: 1-143.

Chen MG, Mott KE 1990. Progress in assessment of morbidity due to Fasciola hepatica infection: a review of recent literature. Trop Dis Bull 87: R1-R38.

De Rijk P, Neefs JM, Van de Peer Y, De Wachter R 1992. Compilation of small ribosomal subunit RNA sequences. Nucl Acids Res 20: 2075-2089.

De Jong RJ, Morgan JAT, Paraense WL, Pointier JP, Amarista M, Ayeh-Kumi PFK, Babiker A, Barbosa CS, Bremond PH, Canese AP, Pereira da Souza C, Dominguez C, File S, Gutierrez A, Incani, RN, Kawano T, Kazibwe F, Kpikpi J, Lwambo NJS, Mimpfoundi R, Njiokou F, Poda JN, Sene M, Velasquez LE, Yong M, Adema CM, Hofkin BV, Mkoji GM, Loker ES 2001. Evolutionary relationships and biogeography of Biomphalaria (Gastropoda: Planorbidae) with implications regarding its role as host of the human bloodfluke, Schistosoma mansoni. Mol Biol Evol 18: 2225-2239.

Dreyfuss G, Abrous M, Rondelaud D 2000. The susceptibility of Lymnaea fuscus to experimental infection with Fasciola hepatica. J Parasitol 86: 158-160.

Dreyfuss G, Moukrim A, Rondelaud D, Vareille-Morel C 1994. Field observations concerning infection of Lymnaea palustris by Fasciola hepatica. J Helminthol 68: 115-118.

Esteban JG, Flores A, Aguirre C, Strauss W, Angles R, Mas-Coma S 1997a. Presence of very high prevalence and intensity of infection with Fasciola hepatica among Aymara children from the northern Bolivian Altiplano. Acta Trop 66: 1-14.

Esteban JG, Flores A, Aguirre C, Strauss W, Angles R, Mas-Coma S 1997b. A population-based coprological study of human fascioliasis in a hyperendemic area of the Bolivian Altiplano. Trop Med Int Health 2: 695-699.

Esteban JG, Flores A, Angles R, Mas-Coma S 1999. High endemicity of human fascioliasis between Lake Titicaca and La Paz valley, Bolivia. Trans Roy Soc Trop Med Hyg 93: 151-156.

Esteban JG, Gonzalez C, Bargues MD, Angles R, Sanchez C, Naquira C, Mas-Coma S 2002. High fascioliasis infection in children linked to a man-made irrigation zone in Peru. Trop Med Int Health 7: 339-348. 
Folmer O, Black M, Lutz R, Vrijenhoek R 1994. DNA primers for amplification of mitochondrial cytochrome $\mathrm{c}$ oxidase subunit I from diverse metazoan invertebrates. Mol Mar Biol Biotechnol 3: 294-299.

Fuentes MV, Malone JB, Mas-Coma S 2001.Validation of a mapping and predicting model for human fasciolosis transmission in Andean very high altitude endemic areas using remote sensing data. Acta Trop 79: 87-95.

Fuentes MV, Valero MA, Bargues MD, Esteban JG, Angles R, MasComa S 1999. Analysis of climatic data and forecast indices for human fascioliasis at very high altitude. Ann Trop Med Parasitol 93: 835-850.

Gironés N, Valero MA, García-Bodelón MA, Chico-Calero MI, Punzón C, Fresno M, Mas-Coma S 2007. Immune suppression in advanced chronic fascioliasis: an experimental study in a rat model. J infect Dis 195: 1504-1512.

Gonzalez LC, Esteban JG, Bargues MD, Valero MA, Ortiz P, Naquira C, Mas-Coma S 2011. Hyperendemic human fascioliasis in Andean valleys: an altitudinal transect analysis in children of Cajamarca province, Peru. Acta Trop 120: 119-129.

Hanelt B, Adema CM, Mansour MH, Loker ES 1997. Detection of Schistosoma mansoni in Biomphalaria using nested PCR. J Parasitol 83: 387-394

Hillyer GV, Soler de Galanes M, Rodriguez-Perez J, Bjorland J, Silva de Lagrava M, Guzman SR, Bryan RT 1992. Use of the Falcon $^{\mathrm{TM}}$ assay screening test-enzyme-linked immunosorbent assay (FAST-ELISA) and the enzyme-linked immunoelectrotransfer blot (EITB) to determine the prevalence of human fascioliasis in the Bolivian altiplano. Am J Trop Med Hyg 46: 603-609.

Hubendick B 1951. Recent Lymnaeidae. Their variation, morphology, taxonomy, nomenclature and distribution. Kungl Svenska Vetenskapsakad Handl Fjärde Ser 3: 1-223 + 5 pl.

Hylton Scott MI 1954. Sobre Limnaeidae argentinos (Mol. Pulm.). Physis Buenos Aires 20: 401-408.

Inaba A 1969. Cytotaxonomic studies of lymnaeid snails. Malacologia 7: 143-168.

Jorgensen A, Madsen H, Nalugwa A, Nyakaana S, Rollinson D, Stothard JR, Kristensen TK 2011. A molecular phylogenetic analysis of Bulinus (Gastropoda: Planorbidae) with conserved nuclear genes. Zool Scr 40: 126-136.

Kaczorkiewick AJ 1983. Distomatosis en la provincia de Neuquén. Rev Med Vet Buenos Aires 64: 354-356.

King PP, Broderip WJ 1832. Description of the Cirrhipeda, Conchifera and Mollusca, in a collection formed by the officers of H.M.S. Adventure and Beagle employed between the years 1826 and 1830 in surveying the southern coasts of South America, including the Straits of Magalhaens and the coast of Tierra del Fuego. Zoological J 5: 332-349.

Kleiman F, Pietrokovsky S, Prepelitchi L, Carbajo AE, WisniveskyColli C 2007. Dynamics of Fasciola hepatica transmission in the Andean Patagonian valleys, Argentina. Vet Parasitol 145: 274-286.

Larrea H, Oviedo ML, Huaman P 1994. Estudio anatómico de Lymnaea diaphana King, 1830, agente transmisor de la fascioliasis en la zona sur del Perú. Bol Lima 16: 95-100.

Lin CP, Danforth BN 2004. How do insect nuclear and mitochondrial gene substitution patterns differ? Insights from Bayesian analyses of combined datasets. Mol Phylogenet Evol 30: 686-702.

Liu L, Mondal MM, Idris MA, Lokman HS, Rajapakse PJ, Satrija F, Diaz JL, Upatham ES, Attwood SW 2010. The phylogeography of Indoplanorbis exustus (Gastropoda: Planorbidae) in Asia. Parasite Vector 3: 57.
Malek EA 1985. Snail hosts of schistosomiasis and other snail-transmitted diseases in tropical America: a manual, Scientific Publication 478, Pan American Health Organization, Washington, 325 pp.

Mas-Coma S 2005. Epidemiology of fascioliasis in human endemic areas. J Helminthol 79: 207-216.

Mas-Coma S, Bargues MD 2009. Populations, hybrids and the systematic concepts of species and subspecies in Chagas disease triatomine vectors inferred from nuclear ribosomal and mitochondrial DNA. Acta Trop 110: 112-136.

Mas-Coma S, Funatsu IR, Bargues MD 2001. Fasciola hepatica and lymnaeid snails occurring at very high altitude in South America. Parasitology 123: S115-S127.

Mas-Coma S, Valero MA, Bargues MD 2008. Effects of climate change on animal and zoonotic helminthiasis. Rev Sci Tech 27: 443-457.

Mas-Coma S, Valero MA, Bargues MD 2009a. Fasciola, lymnaeids and human fascioliasis, with a global overview on disease transmission, epidemiology, evolutionary genetics, molecular epidemiology and control. Adv Parasitol 69: 41-146.

Mas-Coma S, Valero MA, Bargues MD 2009b. Climate change effects on trematodiases, with emphasis on zoonotic fascioliasis and schistosomiasis. Vet Parasitol 163: 264-280.

Mera y Sierra R, Agramunt VH, Cuervo P, Mas-Coma S 2011. Human fascioliasis in Argentina: retrospective overview, critical analysis and baseline for future research. Parasit Vectors 4: 104.

Mera y Sierra R, Artigas P, Cuervo P, Deis E, Sidoti L, Mas-Coma S, Bargues MD 2009. Fascioliasis transmission by Lymnaea neotropica confirmed by nuclear rDNA and mtDNA sequencing in Argentina. Vet Parasitol 166: 73-79.

Morales MA, Luengo J, Vasquez O 2000. Distribución y tendencia de la fasciolasis en el ganado de abasto en Chile, 1989-1995. Parasitol Dia 24: 115-118.

Olaechea FV 1994. Epidemiologia y control de Fasciola hepatica en la Argentina. In A Nari, C Fiel, Enfermedades parasitarias de importancia económica en bovinos, Editorial Agropecuaria, Montevideo, p. 213-232.

Paraense WL 1976. Lymnaea viatrix: a study of topotypic specimens (Mollusca: Lymnaeidae). Rev Bras Biol 36: 419-428.

Paraense WL 1984. Lymnaea diaphana: a study of topotypic specimens (Pulmonata: Lymnaeidae). Mem Inst Oswaldo Cruz 79: 75-81.

Pilsbry HA 1911. Non-marine Mollusca of Patagonia. In Reports of the Princeton University expeditions to Patagonia, 1896-1899, vol. 3, Part 5, p. 513-633.

Posada D 2008. jModeltest: phylogenetic model averaging. Mol Biol Evol 25: 1253-1256.

Posada D, Buckley TR 2004. Model selection and model averaging in phylogenetics: advantages of the AIC and Bayesian approaches over likelihood ratio tests. Syst Biol 53: 793-808.

Remigio EA 2002. Molecular phylogenetic relationships in the aquatic snail genus Lymnaea, the intermediate host of the causative agent of fascioliasis: insights from broader taxon sampling. Parasitol Res 88: 687-696.

Remigio EA, Blair D 1997a. Molecular systematics of the freshwater snail family Lymnaeidae (Pulmonata: Basommatophora) utilising mitochondrial ribosomal DNA sequences. J Moll Stud 63: 173-185.

Remigio EA, Blair D 1997b. Relationships among problematic North American stagnicoline snails (Pulmonata: Lymnaeidae) reinvestigated using nuclear ribosomal DNA internal transcribed spacer sequences. Can J Zool 75: 1540-1545. 
Remigio EA, Hebert PD 2003. Testing the utility of partial COI sequences for phylogenetic estimates of gastropod relationships. Mol Phylogenet Evol 29: 641-647.

Rochebrune AT, Mabille J 1885. Diagnoses de mollusques nouveaux, recueillis par les membres de la mission du Cap Horn et M. Lebrun, Préparateur au Muséum, chargé d'une mission à Santa-Cruz de Patagonie. Bull Soc Philomat Paris 7: 100-111.

Ronquist F, Huelsenbeck JP 2003. MrBayes 3: Bayesian phylogenetic inference under mixed models. Bioinformatics 19: 1572-1574.

Rubel D, Prepelitchi L, Kleiman F, Carnevale S, Wisnivesky-Colli C 2005. Estudio del foco en un caso de fasciolosis humana en Neuquén. Medicina Buenos Aires 65: 207-212.

Saitou N, Nei M 1987. The neighbour-joining method: a new method for reconstructing phylogenetic trees. Mol Biol Evol 4: 406-425.

Samadi S, Roumegoux A, Barges MD, Mas-Coma S, Yong M, Pointier JP 2000. Morphological studies of lymnaeid snails from the human fascioliasis endemic zone of Bolivia. J Moll Stud 66: 31-44.

Sanger F, Nicklen S, Coulson AR 1977. DNA sequencing with chainterminating inhibitors. Proc Nat Acad Sci USA 74: 5463-5467.

Sielfeld W 2001. Phylum Mollusca. Guias de identificación y biodiversidad. Fauna Chilena, Universidad Arturo Prat, Iquique, 15 pp.

Simon C, Franke A, Martin A 1991. The polymerase chain reaction: DNA extraction and amplification. In GM Hewitt, AWB Johnston, JPW Young, Molecular techniques in taxonomy, SpringerVerlag, Berlin, p. 329-355.

Spithill TW, Smooker PM, Copeman DB 1999. Fasciola gigantica: epidemiology, control, immunology and molecular biology. In JP Dalton, Fasciolosis, CAB International Publishing, Wallingford, p. 465-525.

Swofford DL 2002. PAUP*: phylogenetic analysis using parsimony (*and other methods), version 4.01b, Sinauer Associates, Sunderland, Massachusetts.

Tamura K, Peterson D, Peterson N, Stecher G, Nei M, Kumar S 2011. MEGA5: Molecular Evolutionary Genetic Analyses using likelihood, distance and parsimony methods. Mol Biol Evol 28: 2731-2739.

Tantalean M, Huiza A, Capuñay R 1974. Los hospederos intermediarios de Fasciola hepatica en el Perú. I. Estudio de la infección natural y experimental de Lymnaea viator, L. diaphana y Physa venustula. Biota 10: 243-250.

Thompson JD, Higins DG, Gibson TJ 1994. CLUSTALW: improving the sensitivity and progressive multiple sequence alignment through sequence weighting, positions-specific gap penalties and weight matrix choice. Nucl Acids Res 22: 4673-4680.

Torgerson P, Claxton J 1999. Epidemiology and control. In JP Dalton, Fasciolosis, CAB International Publishing, Wallingford, p. 113-149.

Valdovinos C 2006. Estado de conocimiento de los gastropodos dulceaquícolas de Chile. Gayana 70: 88-95.

Valero MA, Darce NA, Panova M, Mas-Coma S 2001. Relationships between host species and morphometric patterns in Fasciola hepatica adults and eggs from the northern Bolivian Altiplano hyperendemic region. Vet Parasitol 102: 85-100.

Valero MA, Gironés N, García-Bodelón MA, Periago MV, ChicoCalero I, Khoubbane M, Fresno M, Mas-Coma S 2008. Anaemia in advanced chronic fasciolosis. Acta Trop 108: 35-43.

Valero MA, Mas-Coma S 2000. Comparative infectivity of Fasciola hepatica metacercariae from isolates of the main and secondary reservoir animal host species in the Bolivian Altiplano high human endemic region. Folia Parasitol 47: 17-22.

Valero MA, Navarro M, García-Bodelón MA, Marcilla A, Morales M, García JE, Hernandez JL, Mas-Coma S 2006. High risk of bacterobilia in advanced experimental chronic fasciolosis. Acta Trop 100: 17-23.

Valero MA, Santana M, Morales M, Hernandez JL, Mas-Coma S 2003. Risk of gallstone disease in advanced chronic phase of fascioliasis: an experimental study in a rat model. $J$ Infect Dis 188: 787-793.

Wethington AR, Lydeard C 2007. Molecular phylogeny of Physidae (Gastropoda: Basommatophora) based on mitochondrial DNA sequences. J Moll Stud 73: 241-257.

Winnepennickx B, Backeljau T, Van de Peer Y, De Wachter R 1992. Structure of the small ribosomal subunit RNA of the pulmonate snail, Limicolaria kambeul, and phylogenetic analysis of the Metazoa. FEBS Lett 309: 123-126.

Zilch A 1959-1960. Gastropoda (Euthyneura). In O Schindewolf, Handbuch der paleozoologie, Borntraeger, Berlin, p. 91-102. 
Nucleotide differences found in the complete $18 \mathrm{~S}$ ribosomal DNA (rDNA) sequence

of the lymnaeid species compared and their location in the secondary structure

Variable areas

Helix

Position

Lymnaea (Lymnaea) stagnalis

Omphiscola glabra

Galba truncatula

Lymnaea cubensis

Lymnaea viatrix $=$ Lymnaea neotropica

Lymnaea humilis

Pseudosuccinea columella

Lymnaea diaphana

Radix auricularia

Radix balthica

Total variable positions $(\mathrm{n}=62)$
Lymnaea (Stagnicola) palustris

$\begin{array}{llllllll}\text { VVVVV } & \text { V } & \text { VVVVVVVVVV VVVVVVVVVV } & \text { VVVVVVVVVV } & \text { V } & \text { VV } & \text { VV } & \text { VV } \\ 111112 & 2222222222 & 2222222222 & 2222222222 & 2 & 45 & 79 & 99\end{array}$

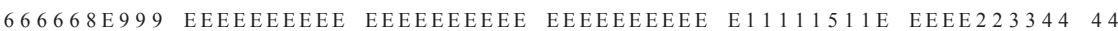

$8 \quad 111111111111111111111111111111122222882222278251347$

$000000000000000000000000000001 \quad 111111$

[...........................

$111111111111111111111111111111 \quad 125777$

11111111
11110

$11111222222222222222222222 \quad 2222222222 \quad 3333334557 \quad 7788123347$

$6777925550 \quad 3333333444 \quad 4444445555 \quad 5555556666 \quad 1999996882 \quad 4935530133 \quad 59$

$9234892786 \quad 345678901234567901234567890126 \quad 2145784025 \quad 749664376323$

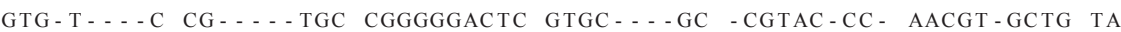
$\ldots . \mathrm{CA} \ldots \ldots \ldots \ldots \ldots \ldots$

TAAC . . . . . . . . . . . . . . . . . . . .

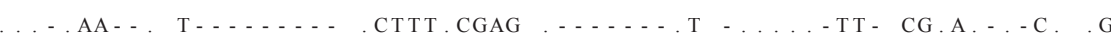

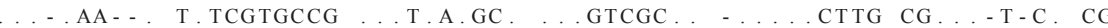

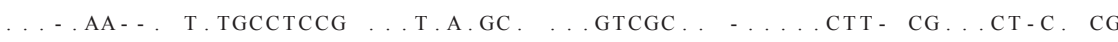
$\ldots . \mathrm{AA}-\mathrm{T}$ T $\ldots . . \mathrm{CG} \ldots \mathrm{C} \cdot \mathrm{AGGC} . \mathrm{A} \cdot \mathrm{G}-\ldots . \ldots \mathrm{CTT}-\mathrm{CG} \ldots \mathrm{CT}-\mathrm{CC}$ CG

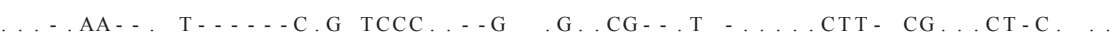

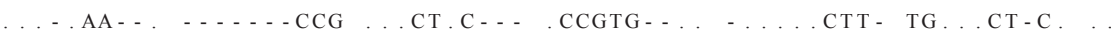

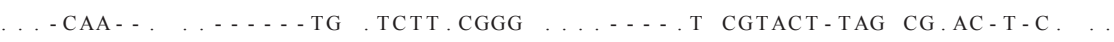

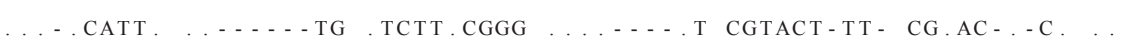

$111111111111222222222233333333333 \quad 4444444444 \quad 555555555566$ $1234567890 \quad 1234567890 \quad 1234567890 \quad 1234567890 \quad 1234567890 \quad 1234567890 \quad 12$

numbers (to be read in vertical) refer to positions obtained in the alignment made with MEGA 5.0. Shaded area corresponds to variable area V2 and helix E10-1 where Lymnaeidae differences in the 18S rRNA gene are concentrated. $\because$ identical; -: indel. 
Polymorphic sites $(\mathrm{n}=108)$, including parsimony informative, singleton sites and gapped or ambiguous characters, detected in the mitochondrial DNA and 16S ribosomal DNA gene sequence alignment of the lymnaeid species compared according to MEGA 5.0

\begin{tabular}{|c|c|}
\hline & $\begin{array}{r}111111111111111111111111111111122222222222222222222222233333333333333333344444444444444 \\
111112222223335555577013333334444444555555666678999900034444444555555778889900000001122566689900011233334444 \\
15670123450152345746160345690123467456789024520578901242456789023568896897801234585818912308903825403480234\end{array}$ \\
\hline$a$ & 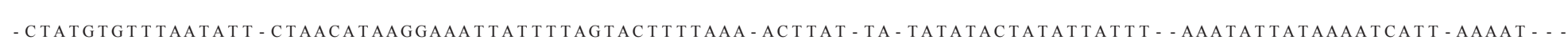 \\
\hline Lymnaea humilis & 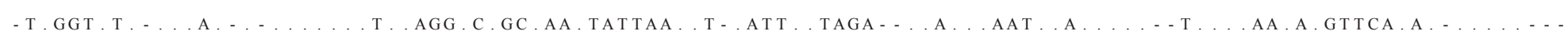 \\
\hline Lymnaea cubensis & 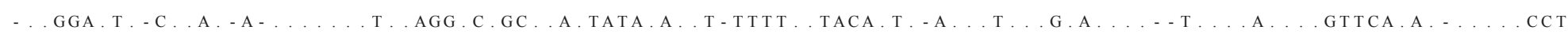 \\
\hline udosuc & 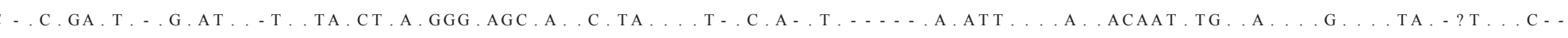 \\
\hline Stagnicola elodes & 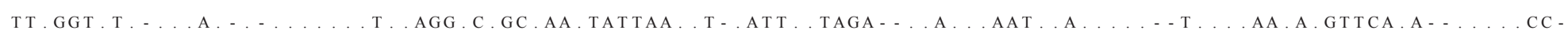 \\
\hline Fossaria obrussa & 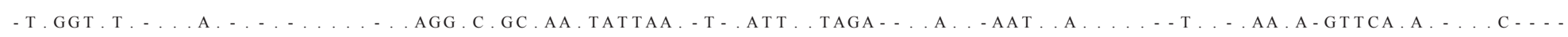 \\
\hline Fossaria bulimoides ${ }^{a}$ & 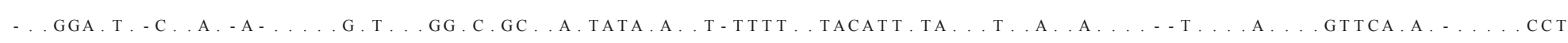 \\
\hline Fossaria bulimoides ${ }^{\mathrm{b}}$ & 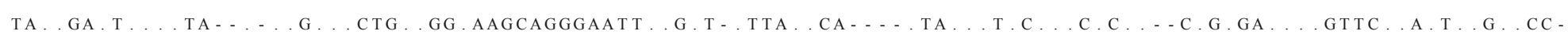 \\
\hline Fossaria bonnevillensis & $\ldots$ G \\
\hline
\end{tabular}

$a:$ AF485657; $b$ : EU038315; $:$ identical; -: indel?.

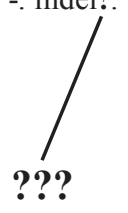

